\title{
THE RELATIONSHIP OF APRI SCORE (ASPARTATE AMINOTRANS FERASE-TO-PLATELET RATIO INDEX) AND PUGH CHILD SCORE
}

\author{
Adelia Muhlifa Saputri ${ }^{1}$, Magdaleni A. R. ${ }^{2}$, Sinta Murti ${ }^{3}$ \\ ${ }^{1}$ Medical Education Study Program, Medical School of Mulawarman University, Samarinda, \\ Indonesia \\ ${ }^{2}$ Physiology Laboratory, Medical School of Mulawarman University, Samarinda, Indonesia \\ ${ }^{3}$ Internal Medicine Laboratory, Medical School of Mulawarman University, Samarinda, Indonesia \\ *E-mail: adelmufl@gmail.com
}

\begin{abstract}
Liver cirrhosis is the last stage of chronic liver disease that is in the path of the disease can cause damage of liver function and/or portal hypertension. The prognosis of liver cirrhosis can be assessed by manifestations of liver function disorders with Child Pugh score that include the presence or absence of ascites, encephalopathy, bilirubin serum, albumin serum, and prothrombin time or INR, while portal hypertension also occurs in patient of cirrhosis can lead the formation of esophageal varices. APRI score has platelet count and AST serum as its variable is suspected to be related to the Child Pugh score in assessing prognosis of cirrhosis patients. This study purposed to find the relation between APRI score (Aspartate Aminotransferase-to-Platelet Ratio Index) and Child Pugh score. Purpose of this research is to find the relation between APRI score (Aspartate Aminotransferase-to-Platelet Ratio Index) and Child Pugh score and degree of esophageal varices in patients with cirrhosis. Method used is a retrospective analytic study with cross sectional approach. The data source is secondary source. The sample in this study were patients with liver cirrhosis who were diagnosed by a doctor and had complied the inclusion criteria. The data obtained was analyzed using ANOVA.

The result of this study is include 48 cirrhosis patients, male $81,3 \%$, with a mean age 49,98 years. The most common cause of cirrhosis is hepatitis B obtained from reactive HBsAg examination in 33 patients $(68,8 \%)$. The APRI score was found to have a weak correlation $(r=0.044)$ and not significant $(\mathrm{p}=0.868)$ with the Child Pugh score. The APRI score do not able to assess the prognosis in advanced cirrhotic patients.
\end{abstract}

Keywords: Apri score, child pugh, cirrhosis

\section{INTRODUCTION}

Cirrhosis of the liver is the last stage of chronic liver disease which in the course of the disease can cause impaired liver function and/or portal hypertension ${ }^{1}$. Impaired liver function is 
manifested by the presence of icterus due to increased total serum bilirubin, ascites, changes in mental status, thrombocytopenia due to decreased thrombopoietin production, increased serum aspartate aminotransferase (AST) and alanine transaminase (ALT), and hypoalbuminemia ${ }^{2,3}$. Whereas, portal hypertension results in platelet sequestration in the spleen and the formation of esophageal varices. The appearance of complications such as ascites, encephaloplatepatikum, and rupture of esophageal varices can increase mortality in cirrhosis patients ${ }^{4}$.

The cause of death due to cirrhosis of the liver was ranked 17th out of 235 diseases that cause death in the world in 2010, and ranked 11th in the Southeast Asian region ${ }^{5}$. In Indonesia, on average, there are about $3.5 \%$ of liver cirrhosis patients out of the total number of patients admitted to the Internal Medicine ward of a government hospital ${ }^{6}$.

The prognosis of patients with liver cirrhosis can be predicted by using a corneous, one of which is Child Pugh score ${ }^{7}$. Indicators assessed in this score are sites, encephalopathic hepatic, total bilirubin, serum albumin, prostrombin time, and INR (International Normalized Ratio) ${ }^{8}$. The Child Pugh score has a sensitivity and specificity of $77.7 \%$ and $63 \%$ in assessing prognosis in patients with cirrhosis of the liver. The study also showed that the Child Pugh score was a better indicator in determining the prognosis of patients with liver cirrhosis compared to the MELD (Model for End-Stage Liver Disease) score ${ }^{9}$. The Child Pugh score is considered the most consistent in determining the prognosis of liver cirrhosis patients compared with other scores such as MELD scores or serum ALT levels alone ${ }^{10}$.

At a later stage, most liver cirrhosis patients will manifest in the form of a decrease in the number of platelets that is 70,000-149,000 / $\mu \mathrm{L}$ and an increase in AST levels of 36-175 $\mathrm{U} / \mathrm{L}^{11}$. Platelet count is one of the variables that is often used in predicting mortality in patients with liver cirrhosis ${ }^{10}$. A score is designed that is the APRI (Aspartate Aminotransferase-to-Platelet Ratio Index) score which is considered more objective in determining the presence or absence of cirrhosis in patients with chronic liver disease. This score develops on the assumption that increasing AST counts and decreasing platelet counts are the most important predictors in determining the formation of liver fibrosis in patients with chronic liver disease ${ }^{12}$. In addition, APRI scores can also be used to predict the prognosis in liver cirrhosis patients such as Child Pugh and MELD7 scores. Increased APRI scores are associated with worsening Child Pugh scores and increase the likelihood of a person experiencing decompensated liver cirrhosis ${ }^{13}$.

\section{MATERIAL AND METHOD}

The design of this study was a retrospective analytic cross sectional approach using nonrandom techniques by purposive sampling. The data taken is secondary data derived from medical records of liver cirrhosis patients in Abdul Wahab Sjahranie Hospital in Samarinda with 48 patients. Data analysis was done by using ANOVA test. The APRI score is a comparison between AST levels and platelet counts obtained from laboratory tests during hospitalization with objective cut-off criteria $<0.5=$ non-fibrosis; $0.5-1.5=$ moderate fibrosis; and cut-off $>1.5=$ cirrhosis. Child Pugh score is score obtained from the assessment of the presence or absence of ascites, 
encephalopithepatic, bilirubin levels, albumin levels, and prothrombin time or INR obtained from resumes and laboratory results while the patient is in the hospital.

\section{RESULTS AND DISCUSSION}

In this study, 48 samples were found that met the inclusion and exclusion criteria that had been set.

1. Characteristics of Patients with Cirrhosis Liver

Table 1 Characteristics of Patients with Cirrhosis of the Liver

\begin{tabular}{lllllll}
\hline Characteristic & & (n) & $\mathbf{( \% )}$ & Mean & Min. & Max. \\
\hline Age & Total & 48 & 100 & 49.98 & 24 & 77 \\
Gender & Male & 39 & 81.3 & & & \\
& Female & 9 & 18.8 & & & \\
\hline HbsAg & Reactive & 33 & 68.8 & & & \\
& Non-Reactive & 13 & 27.1 & & & \\
& Undefined & 2 & 4.2 & & & \\
\hline APRI Score & Score $<0.5$ & 1 & 2.1 & 5.102 & 0.1 & \\
& Score $0.5-1.5$ & 14 & 29.2 & & & \\
& Score $>1.5$ & 33 & 68.8 & & & \\
\hline Child Pugh & A & 2 & 4.2 & & & \\
& B & 23 & 47.9 & & & \\
& C & 23 & 47.9 & & & \\
\hline Esophageal Varices & Normal & 20 & 41.7 & & & \\
& Grade 1 & 5 & 10.4 & & & \\
& Grade 2 & 5 & 10.4 & & & \\
& Grade 3 & 18 & 37.5 & & & \\
& & & & &
\end{tabular}

In this study, it was found that the average age of liver cirrhosis patients was 49.98 years with the number of male as many as 39 patients $(81.3 \%)$. The main cause of liver cirrhosis was $68.8 \%$ of hepatitis B obtained from HBsAg examination.

The proportion of liver cirrhosis patients according to age that has been presented in table 1 shows that the mean age of liver cirrhosis patients is 49.98 years. Not much different compared to a result of research conducted in Texas which was found that liver cirrhosis patients were dominated by the age group above 40 years, 1,798 patients out of 2,017 patients, with an average age of 52 years $^{14}$. This study is also in accordance with research conducted in Medan where the mean age of liver cirrhosis patients was 48.5 years ${ }^{15}$. This can occur because cirrhosis of the liver is a chronic disease of the liver with new symptoms and signs that will appear years later after prolonged exposure by a risk factor or a history of hepatitis virus infection ${ }^{16}$.

Table 1 also shows that the proportion of patients with liver cirrhosis in male is higher $(81.3 \%)$ than female $(18.8 \%)$. This study is in accordance with research conducted in Manado which found that more male were suffering from liver cirrhosis $(62.7 \%)$ than female $(37.7 \%){ }^{17}$. Research in Singapore also found that liver cirrhosis patients were dominated by men with 360 patients $(63.4 \%)$ out of 564 patients taken as samples ${ }^{18}$. 
It is not yet known for sure the cause of male tendency to suffer more cirrhosis of the liver than female. However, it is allegedly caused by the position of male as the head of the household which required them to work harder and rarely pay attention to their physical and mental health so that they tend to be more susceptible to disease. In western countries, men tend to suffer more from liver cirrhosis due to the habit of consuming alcohol ${ }^{19}$.

Based on research conducted at Abdul Wahab Sjahranie Hospital in Samarinda, it was also found that the most common cause of cirrhosis was hepatitis B virus infection as proven by the large number of reactive HBsAg results (68.8\%). This is in line with research conducted in Manado which got the highest cause of liver cirrhosis due to hepatitis B virus infection as much as $37.3 \%$ and research in Pontianak also found that the most cause of liver cirrhosis was hepatitis B virus $(35.63 \%)^{17,20}$.

The result in table 1 shows that the highest APRI score is $>1.5(68.8 \%)$ or indicates that the patient is in advanced fibrosis or cirrhosis. The average APRI score obtained from this study was 5.102 with a minimum score of 0.1 and a maximum of 45.6. This result is the same as the research conducted in Pontianak which obtained APRI scores with minimum (0.08) and maximum (16.08) scores that had a very wide range and were not normally distributed. This very wide range is likely due to the small number of research subjects and the presence of diverse etiologies and some data not mentioning a history of hepatitis or a history of alcohol consumption ${ }^{20}$.

The result in table 1 illustrates that the classification of the highest Child Pugh score was Child Pugh B, as many as 23 patients (47.9\%) and Child Pugh C as many as 23 patients (47.9\%). Research conducted by Poernomo (2015) in Yogyakarta also shows that the Child Pugh B class is more dominant $(61.11 \%)$ than the Child Pugh C class (39.89\%) as well as in research conducted in Manado where Child Pugh $\mathrm{C}$ dominate the result of the most type suffered by liver cirrhosis patients, as many as 20 people (64.5\%), followed by the Child Pugh B of 7 people (22.6\%), and the Child Pugh A of 3 people (9.7\%) ${ }^{21,22}$.

Research that has been done also shows that people suffering from cirrhosis of the liver majorly suffer from large esophageal varices or grade 3, of 18 patients $(37.5 \%)$ from the population. Likewise, in line with the previous research in which it shows that people with liver cirrhosis mostly suffer from grade 3 esophageal varices, as many as 47 people $(71.2 \%)^{23}$.

\section{The Relationship between APRI (Aspartate Aminotransferase-to-Platelet Ratio Index) score and Child Pugh Score}

Table 2 2. The Relationship between APRI score and Child Pugh Score

\begin{tabular}{lcccccc}
\hline \multirow{1}{*}{ APRI Score } & \multicolumn{3}{c}{$\begin{array}{c}\text { Child Pugh } \\
\text { Classification }\end{array}$} & Total & $\begin{array}{c}\mathbf{p} \\
\text { value }\end{array}$ & Correlation \\
\cline { 2 - 5 } & A & B & C & & & \\
\hline Non-Fibrosis & 0 & 1 & 0 & 1 & 0.868 & 0.044 \\
(score< 0.5) & 1 & 6 & 7 & 14 & & \\
Moderate Fibrosis & & & & &
\end{tabular}




\begin{tabular}{lllll}
\hline $\begin{array}{l}\text { (score 0.5-1.5) } \\
\text { Cirrhosis } \\
(\text { score }>1.5)\end{array}$ & 1 & 16 & 16 & 33 \\
Total & 2 & 23 & 23 & 48 \\
\hline
\end{tabular}

In this study, it was found that the majority of liver cirrhosis patients were in the APRI score group > 1.5 category in the Child Pugh B and C classes as many as 23 people for each classification. The results of the analysis of the relationship between APRI scores and Child Pugh scores obtained a weak correlation $(\mathrm{r}=0.044)$ and is insignificant as indicated by a $\mathrm{p}$ value of 0.868 . The value of $\alpha$ is 0.05 . This indicates that there is no significant relationship between APRI scores and Child Pugh scores seen from $p$ values that are greater than $\alpha$ values.

It also stated that in assessing the development of annual liver cirrhosis the APRI score did not have a significant relationship with the severity of liver cirrhosis $(\mathrm{p}=0.228)$. Previous studies also showed the value of limited APRI changes in predicting the development of liver cirrhosis ${ }^{24}$.

However, different from research in Karnataka in which it also found a significant relationship between APRI scores and Child Pugh scores ( $\mathrm{p}$ value $<0.001$ ). In this study, it was also found that the higher the APRI score, the higher the Child Pugh class of the patient would be, so that the APRI score can also be used to predict mortality in liver cirrhosis patients ${ }^{7}$. Research in Pontianak also found that the statistical test results of APRI scores and the severity of liver cirrhosis as measured by Child Pugh scores showed a significant relationship $(\mathrm{p}=0.005)^{20}$.

The APRI score uses a variable that is thought to be the most important predictor in determining the presence or absence of fibrosis in patients with chronic liver disease, namely AST levels and platelet counts ${ }^{12}$. Increased AST levels and decreased platelet counts can be a sign that liver damage is in the advanced phase ${ }^{11}$.

Although the main mechanism of decreasing platelets or thrombocytopenia in patients with chronic liver disease is the presence of platelet askuesteration in the spleen and a decrease in the production of thrombopoietin in the liver, platelet reduction can also be caused by various other factors, namely cirrhosis of the coagulopathy, bone marrow suppression by chronic infection of the hepatic $\mathrm{C}$ virus and reduction in thrombopoietin production in the liver, but the decrease in platelets can also be caused by various other factors, such as cirrhosis of coagulopathy, suppression of bone marrow by chronic infection of the hepatitis $\mathrm{C}$, and the liver anti-cancer agents as well as antiviral treatment with interferon-based therapy can also contribute to the development of thrombocytopenia in cirrhosis patients ${ }^{25}$.

In addition, the development of a state of fibrosis in the liver can also reduce AST clearance and injure mitochondria so that it will increase serum $\mathrm{AST}^{12}$ levels. AST is an enzyme that can be found in the liver that functions as a catalyst for aspartate and alpha-ketoglutarate to oxaloacestates and gluamates. Although AST enzymes are mainly found in liver cells, some cells such as red blood cells, heart cells, muscle cells, pancreas, and kidneys can also produce these enzymes ${ }^{26}$.

In patients with advanced liver disease or atarosis, there is often a subtle change in laboratory values to within the normal range. Therefore, laboratory studies cannot be used as a single 
screening tool in assessing patient prognosis. By identifying risk factors, physical examination, and laboratory tests, it will get better results to determine the patient's prognosis ${ }^{27}$.

\section{CONCLUSION}

There is no relationship between APRI score and Child Pugh score on liver cirrhosis patients at Abdul Wahab Sjahranie Hospital in Samarinda so that the APRI score cannot replace the Child Pugh score in determining the prognosis of liver cirrhosis patients.

\section{REFERENCE}

1. Samonakis, D. N., Koulentaki, M., Coucoutsi, C., Augoustaki, A., Baritaki, C., et al.Clinical Outcome of Compensated and Decompensated Cirrhosis: A Long Term Study. World Journal of Hepatology, 6(7), 504-512(2014)..

2. Heidelbaugh, J. J., \& Bruderly, M. Cirrhosis and Chronic Liver Failure: Part I. Diagnosis and Evaluation. American Family Physician, 74(5), 756-762(2006).

3. Muir, A. J. Understanding the Complexities of Chirrosis. Clinical Therapeutics, 37(8), 1822-1836(2015).

4. Verhelst, X., Geerts, A., Vlierberghe, H. V. Cirrhosis: Reviewing The LiteratureAnd Future Perspectives. European Medical Journal, 1(3), 111-117(2016).

5. Lozano, R., Naghavi, M., Foreman, K., Lim, S., Shibuya, K., et al. Global and Regional Mortality from 235 Causes of Death for 20 Age groups in 1990 and 2010: A Systemic Analysis for the Global Burden of Disease Study 2010. Lancet, 380, 2095-2128(2012).

6. PPHI.Artikel Umum: Sirosis Hati. Tersedia dari: http://pphionline.org/alpha/?p=570.(2013). [Diakses: Desember 2018]

7. George, J., Yeshavanth, G. Correlation between APRI Index, MELD Score, and Child Pugh Score in Cirrhosis of Liver. Journal of Medicine Science and Clinical Research, 6(5)(2018).

8. Peng, Y., Qi, X., Guo, X. Child-Pugh Versus MELD Score for the Assessment of Prognosis in Liver Cirrhosis. Medicine, 95(8)(2016)..

9. Shaikh, S., Ghani, H., Memon, S., Baloch, G. H., Jaffrey, M., \& Shaikh, K. MELD Era: Is This Time to Replace the Original Child-Pugh Score in Patients with Decompensated Cirrhosis of Liver. Journal of College of Physicians and Surgeons Pakistan, 20(7), 432435(2010)..

10. D'Amico, G., Gracia-Tsao, G., \& Pagliaro, L. Natural History and Prognostic Inc=dicators of Survival in Cirrhosis: A Systematic Revies of 118 Studies. Journal of Hepatology, 44, 217-231(2006)..

11. Husni, N., Anniwati, L., \& Lukitasari, L. Aspartate Aminotransferase to Platelet Ratio Index Profile of Cirrhotic Patients with Positive HBsAg. Journal of Aesculap Medical Science, $\boldsymbol{X}(01)$, 34-37(2019).. 
12. Wai, C.-T., Greenson, J. K., Fontana, R. J., Kalbfleisch, J. D., Marrero, J. A., Conjeevaram, H. S., et al. A Simple Noninvasive Index Can Predict Both Significant Fibrosis and Chirrhosis in Patients With Chronic Hepatitis C. Hepatology, 38(2), 518-526(2003)..

13. Mao, W., Sun, Q., Fan, J., Lin, S., \& Ye, B. AST to Platelet Ratio Index Predicts Mortality in Hospitalized Patients With Hepatitis B-Related Decompensated Cirrhosis. Medicine,95(9)(2016)..

14. Sajja, K. C., Mohan, D. P., \& Rockey, D. C. Age and Etnicity in Cirrhosis. J Investig Med, 62(7), 920-926(2014).

15. Tarigan, E., Dairy, L. B., Sihombing, J. S. M., Siregar, G. A., Zain, L. H.S-Index and APRI Score to Predict Liver Fibrosis Chronic in Hepatitis B and C Patients. The Indonesian Journal of Gastroenterology, Hepatology, and Digestive Endoscopy, 14(2), 64-68(2013)..

16. Stiphany, Hiswani, \& Jemadi. Karakteristik Penderita Sirosis Hati Rawat Inap di RSUD Dr. Pirngadi Medan Tahun 2010-2011. Universitas Sumatera Utara, Fakultas Kesehatan Masyarakat, Medan(2012).

17. Patasik, Y. Z., Waleleng, B. J., Wantania, F. Profil Pasien Sirosis Hati yang Dirawat Inap di RSUP Prof. Dr. R. D. Kandou Manado Periode Agustus 2012 - Agustus 2014. Jurnal e-Clinic, 3(1)(2015).

18. Chang, P. E., Wong, G. W., Li, J. W., Lui, H. F., Chow, W. C., \& Tan, C. K. Epidemiology and Clinical Evolution of Liver Cirrhosis in Singapore. Annals Academy of Medicine, 44(6), 218-225(2015)..

19. Karina, Faktorrisikokematianpenderitasirosishati di RSUP Dr. Kariadi Semarang Tahun 2002-2006.Artikel

karyatulisilmiahmahasiswaFakultasKedokteranUniversitasDiponegoro. Tersediadari: http://eprints.undip.ac.id/22681/1/Karina.pdf. (2007). [Diakses: Mei 2019]

20. Herlida,HubunganSkor APRI (Aspartat Aminotransferase-to-Platelet Ratio Index) denganDerajatKeparahanSirosisHati di RSUD

DokterSoedarsoPontianak.NaskahpublikasimahasiswaFakultasKedokteran dan IlmuKesehatanUniversitasTanjungpura.

Tersediadari: https://media.neliti.com/media/publications/194580-ID-none.pdf. （2007). [Diakses: Desember 2018]

21. Poernomo, T. P.,Prediktor Prognosis JangkaPendekPenderitaSirosisHatiDekompensata.TesismahasiswaFakultasKedokteranUn iversitas Gadjah Mada. Tersediadari: etd.repository.ugm.ac.id/downloadfile/83536/potongan/S2-2015375432.title.pdf.(2015).[Diakses: Mei 2019]

22. Poluan, P. M., Kawengian, V., \& Sugeng, C. Hubungan Derajat Keparahan Sirosis Hati dan Nilai Laju Glomerulus pada Sirosis Hati. Jurnal e-Clinic (eCl),3(1), 497-502(2015).

23. Elfatma, Y., Arnelis, \& Rachmawati, N. Gambaran Derajat Varises Esofagus Berdasarkan Beratnya Sirosis Hepatis. Jurnal Kesehatan Andalas, 6(2), 457-462(2017). 
24. Xiao, L., Wang, W., Xian, J., Zhang, W., Li, Y., Yang, X., Lu, L. Annual Change in FIB4, but not in APRI, was a Strong Predictor for Liver Disease Progression in Chinese Patients with Chronic Hepatitis C. HepatMon, 18(3)(2018).

25. Hayashi, H., Beppu, T., Shirabe, K., Maehara, Y., \& Baba, H. Management of Thrombocytopenia due to Liver Cirrhosis: A Review. World Journal of Gastroenterology, 20(10), 2595-2605(2014).

26. Xing-Jiu, H., Yangkyu, C., Hyungsoon, I., Oktay, Y., Euisik, Y., \& Haksung, K. Review: Aspartate Aminotransferase (AST/GOT) and Alanine Aminotransferase (ALT/GPT) Detection Techniques. Sensors, 6, 756-782(2006).

27. Ahmed, Z., Ahmed, U., Walayat, S., Ren, J., Martin, D. K., Moole, H., Koppe, S., Yong, S., Dhillon, S. Liver Function Test in Identifying Patients with Liver Disease.Clinical and Experimental Gastroenterology, 11, 301-307(2018). 